\title{
The Capacity Needs of Students Majoring in Intelligent Construction Under the Background of Emerging Engineering Education
}

\author{
Hongjie Guan ${ }^{1, *}$, Lefang Zhang ${ }^{1}$ and Guang Yang ${ }^{1}$ \\ ${ }^{1}$ Xi'an Eurasia University, Xi'an, 710065, China \\ *Corresponding author. Email: guanhongjie@eurasia.edu
}

\begin{abstract}
In order to meet the needs for talents generated by the rapid application and development of intelligent construction in China, and obtain the training goal and curriculum system that adapt to the needs of social development, this work conducted research analysis on several employing units, such as high-tech and manufacturing enterprises, construction units, construction units, design institutes, and third-party consulting units. Then, the work determined the post professional quality and post ability requirements of intelligent construction professionals, and put forward some suggestions on talent training and curriculum construction. Keywords: Intelligent construction; Prefabricated building; Research; Capacity need
\end{abstract}

\section{INTRODUCTION}

Intelligent Construction is an emerging engineering major based on the civil engineering major, which is developed by integrating mechanical design, manufacturing and automation, electronic information and automation, engineering management and other majors in the face of national strategic needs and the upgrading and transformation of the construction industry [1]. On July 3, 2020, 13 departments jointly issued the Guidance on Promoting the Coordinated Development of Intelligent Construction and Construction Industrialization, which proposes to strengthen the cultivation of talents. All localities should formulate relevant policies and measures for the cultivation of intelligent construction talents, clarify objectives and tasks, establish long-term mechanisms for the cultivation and development of intelligent construction talents, and create various forms of high-level talent cultivation platforms. It is necessary to strengthen the training of reserve talents, encourage enterprises and institutions of higher learning to deepen cooperation, and provide reserve support for intelligent construction and development [2].

With big data, Internet of things, artificial intelligence and other information technologies leading the transformation and upgrading of the construction industry, the intelligent construction major, as an emerging engineering major, is bound to integrate professional teachers, reconstruct the composition of disciplines and the process of talent training, coordinate the relationship between application, innovation and guidance, and act as a good supplier of application-oriented industrial personnel [3]. Based on the investigation of most types of enterprises in the construction industry, this work discussed the capacity needs of enterprises for students majoring in intelligent construction under the background of emerging engineering, which serves as the basis for the curriculum system of intelligent construction in Xi'an Eurasia University.

\section{RESEARCH METHODS}

\subsection{Questionnaire survey}

In order to ensure the sufficient and effective sample size, this survey adopted the combination of online and offline questionnaire to analyze the results of the questionnaire.

\subsection{Interview research}

This research also adopted the method of visiting or inviting to conduct one-to-one interviews with relevant personnel of enterprises, deeply excavate the business and capacity needs of enterprises for talent training, and look for opportunities and platforms for cooperation between schools and enterprises.

\subsection{Literature research}

Before the investigation, this work conducted relevant literature review and preliminary data collection based on research purposes, mainly including high-tech and manufacturing enterprises, construction units, construction units, design institutes, and third-party consulting units. Through sorting out relevant information and future development direction and needs of these enterprises, the work grasped the background information of the research objects more comprehensively and correctly, and provides 
effective support for the development of the research work.

\subsection{Field research}

This research obtained the first-hand information of the development direction and talent needs of enterprises by field visiting, which has guidance significance to the adjustment of the curriculum system of intelligent construction major.

\section{RESEARCH RESULTS AND ANALYSIS}

\subsection{Research overview}

This research distributed questionnaires to different categories of research personnel through interviews and emails. By the end of the investigation, a total of 300 questionnaires were sent out and 259 were recovered with a recovery rate of $84 \%$, and a total of 17 enterprises were investigated.

\subsection{Research analysis on the industrial present situation and talent needs}

The enterprises in this research include high-tech and manufacturing enterprises, design institutes, construction units, manufacturing factories, and consulting units. Through in-depth interviews, field investigation and literature research, this work grasped a certain understanding of the needs of intelligent construction professionals, post groups, and professional competence requirements. In the construction project, the international investment in intelligent buildings accounts for a considerable proportion. According to statistics, the current investment in intelligent buildings accounts for more than $10 \%$ of the total investment in buildings. In addition, more than 30 provinces and cities have issued guidance and relevant supporting measures for the development of prefabricated architecture and building industrialization, and many places have put forward clear requirements for the development of building industrialization [4]. In May 2017, the Ministry of Housing and Urban-Rural Development issued the 13th Five-Year Plan for the Development of the Construction Industry, which calls for prefabricated buildings to account for at least $15 \%$ of new construction by 2020 . Assuming that the proportion of prefabricated building skilled personnel in the construction industry is consistent with the proportion of prefabricated building area in the newly built building area, that is, the proportion of prefabricated building skills is $15 \%$ in 2020 and $30 \%$ in 2025 . Additionally, according to the studies of some scholars, the number of on-site construction industry employees accounts for $85 \%$ of the total number of construction industry employees, and the number of enterprise management personnel accounts for $15 \%$ [5].

\subsection{Post group research and analysis}

At present, intelligent construction is mainly based on prefabricated buildings; so many jobs are closely combined with prefabricated jobs. By combining factory prefabrication with on-site assembly, factorization not only shortens the construction cycle, but also reduces the dependence on manual labor and labor skills. This means that with the development of prefabricated buildings, there will be no "crowd tactics" in construction in the future.

\subsubsection{Lack of project management talents}

The State Council points out in the Guiding Opinions of the General Office of the State Council on Developing Prefabricated Buildings that the important task of developing prefabricated buildings is to "popularize the general contracting of projects". Therefore, for enterprises, it is necessary to adjust their own organizational structure, establish new management methods, including bidding system and project subcontracting model, and improve the quality, safety, progress and cost management system of prefabricated construction projects. It is necessary to increase the exchanges and cooperation with corresponding design units and component and accessory manufacturers, and form an industrial technology alliance through strong alliance, so as to improve future business undertaking capacity and market competitiveness [6]. Great changes have taken place in prefabricated building projects from design, construction to project delivery and operation. The traditional engineering project managers lack the management thinking of industrialization and the systematic understanding of the design, production and construction process of the whole assembly building [7]. To sum up, the rapid development of prefabricated buildings poses important challenges to practitioners and managers.

\subsubsection{Lack of prefabricated technical talents}

The assembly design process of component and the construction process of assembly also put forward new technical challenges to design and construction. BIM technology plays an important role in assembly building, which can realize the whole professional management of design, construction, construction and operation, and provide data support for the informatization of assembly construction industry. However, there is a serious shortage of talents who master BIM technology and understand the design and construction technology of prefabricated buildings. 


\subsubsection{Lack of new technical talents}

In addition to BIM technology, emerging technologies will play a more and more important role in the development of prefabricated buildings. 3D printing, VR technology, Internet of Things, construction robots and other technologies require current industry practitioners to have a certain understanding of these technologies and the value of technologies in engineering.

\subsection{Professional competency analysis}

Through the investigation of the person in charge of the enterprise and the understanding of the talent market, this work analyzed and sorted out the selection criteria of the enterprise and the factors considered in the recruitment of talents. According to statistics, work attitude, professional ethics, professional skills and team awareness are most valued by enterprises. From the results of this survey, it can be seen that enterprises pay more attention to the work attitude and professional ethics of talents. Whether a person can be active, practical, and responsible to the enterprise service, and whether can be loyal to duty, obey the transfer, abide by the system is the most important quality of the enterprise.

According to the investigation, this work summarized the professional quality and post competency requirements of intelligent construction talents, sees Table 1.

Table 1. Professional quality and post competency requirements sheet

\begin{tabular}{|c|c|c|c|}
\hline & \multirow[t]{2}{*}{ Competency category } & \multicolumn{2}{|c|}{$\begin{array}{l}\text { Level of competency } \\
\text { requirements }\end{array}$} \\
\hline & & Important & General \\
\hline \multirow{7}{*}{ Professional competency } & Drawing and mapping competency & $\sqrt{ }$ & \\
\hline & $\begin{array}{l}\text { Information technology tool selection and application } \\
\text { competency }\end{array}$ & $\sqrt{ }$ & \\
\hline & Mechanical problem solving competency & & $\sqrt{ }$ \\
\hline & Experimental design and operation competency & $\sqrt{ }$ & \\
\hline & Component design competency & $\sqrt{ }$ & \\
\hline & Data organization and analysis competency & $\sqrt{ }$ & \\
\hline & Academic communication competency & & $\sqrt{ }$ \\
\hline \multirow{4}{*}{$\begin{array}{l}\text { Methodological } \\
\text { competency }\end{array}$} & Develop work plans and organize implementation & $\sqrt{ }$ & \\
\hline & Solve practical problem ideas & $\sqrt{ }$ & \\
\hline & Learn new technologies independently & $\sqrt{ }$ & \\
\hline & Evaluate work results & & $\sqrt{ }$ \\
\hline \multirow{8}{*}{ Social competency } & Hardworking and professional dedication & $\sqrt{ }$ & \\
\hline & Pay attention to social development & & $\sqrt{ }$ \\
\hline & Interpersonal and communication skills & $\sqrt{ }$ & \\
\hline & Professional ethics, honesty and trustworthiness & $\sqrt{ }$ & \\
\hline & Teamwork competency & $\sqrt{ }$ & \\
\hline & Etiquette cultivation & & $\sqrt{ }$ \\
\hline & Organization and execution competency & $\sqrt{ }$ & \\
\hline & Lifelong learning competency & $\sqrt{ }$ & \\
\hline \multicolumn{4}{|c|}{$\begin{array}{l}\text { evaluation of undergraduate teaching, the norms of } \\
\text { undergraduate major construction, the certification of } \\
\text { international engineering education, and have the } \\
\text { characteristics of strengthening ability training, } \\
\text { highlighting innovation and entrepreneurship, meeting the } \\
\text { needs of the industry, and conforming to the development } \\
\text { of the industry. }\end{array}$} \\
\hline
\end{tabular}

\subsection{Professional cultivation of students}

Xi'an Eurasian University, as the first university in Northwest China to offer this major, should be more forward-looking and scientific in the training of students in this major, better serve the regional economic and social development, and strive to play a leading role. Therefore, future student training should be in line with the

\subsection{Cultivation of teaching reserve}

As an emerging engineering major, the intelligent construction major is integrated across majors, and the joint training will inevitably require the diversification, double-qualified, international and professionalization of professional teachers. Therefore, in the future teacher planning, the branch should focus on the above factors. 
Owned teachers are encouraged to transform and upgrade, and at the same time, new professional talent reserve should be appropriately tilted in personnel recruitment.

\subsection{Construction of growing platform}

Relying on the studio construction, a growing and development support platform for professional teachers can be constructed. In order to make teachers develop better, the studio provides support and help to teachers in scientific research, curriculum construction and student competition, and plays the role of studio platform.

\subsection{Curriculum development}

The curriculum system and curriculum content should highlight the characteristics of "stability" and "change", ensure the stability of platform courses and civil engineering core basic courses, and adjust the professional courses and new technology integration courses with the changes of the market.

\subsection{Cooperation between enterprises and universities}

In the future, it is imperative to establish industrial colleges by visiting and learning enterprises and by co-building practical teaching bases or projects between schools and enterprises. Through the management system of both sides of enterprises and universities, the diversified investment, the specialized school running and the enterprise management can be used to construct the open cooperative education platform, and establish the new mode of cultivating the characteristic talents of the enterprise.

\subsection{Internship and training}

Internship and training should be carried out around students' future employment direction and positions. The experimental and practical training room should be equipped with assembly-related teaching software, so that teachers can better carry out course construction and also serve the enterprise. It is suggested to add artificial intelligence-related training links, including 3D printing, UAV and VR virtual simulation, so as to meet the requirements of courses and industry-university-research and provide students with a good learning experience.

\section{CONCLUSION}

An intelligent construction major is an emerging major which integrates information technology and engineering construction. Innovative models and methods should be adopted in the training of talents. Colleges and enterprises should cooperate closely to cultivate both cutting-edge technology and new professionals who can meet the needs of the reform of the construction industry.

\section{ACKNOWLEDGMENT}

The work was supported by the second batch of emerging engineering research and practice projects in Shaanxi Province (2020): Curriculum System Construction and Practice of Intelligent Construction Major Based on 3D Scanning and VR Technology-A Case Study of Xi'an Eurasia University (No. 2020 GKSJ001).

\section{REFERENCES}

[1] Zhou Jianliang, Wu Yuexing, Yan Xiaofei. The Development of BIM Technology in the United States and Its Enlightenment to the Transformation and Upgrading of China's Construction Industry [J]. Science and Technology Progress and Policy, 2014 (11): 30-33.

[2] Ouyang Lijun, Wang Qing. Proposal of Intelligent Construction Major and the Exploration of New Ideas of Innovation and Entrepreneurship of College Students [J]. Education Teaching Forum, 2019 (22): 1-4.

[3] Lin Jian. Construction of Emerging Engineering Major with Multi-disciplinary Cross-integration [J]. Research in Higher Education of Engineering, 2018 (1): $32-45$.

[4] Hao Shuang. Development Bottleneck and Countermeasure Research of Prefabricated Building [J]. Housing and Real Estate, 2019 (06).

[5] Liu Tao, Luo Zhiyong, Xu Yi. Thoughts of Talent Training Based on Assembly Building [J]. Journal of Qiqihar Teachers College, 2018 (02).

[6] Qiao Dan. Analysis on the Influencing Factors and Countermeasures of Assembly Construction Engineering Management [J]. Theoretical Research in Urban Construction (Electronic Edition), 2019 (36).

[7] Huang Kuilin. Research on Project Management of Prefabricated Building [J]. Huang Kuilin, China Construction, 2020 (02). 